\title{
Livestock Service through Knowledge of Society: Mainstreaming Contribution of Women Knowledge Holders
}

\author{
Ravikumar R. K. ", Lopamudra Dutta, Amit Bera and Vipin Kumar
}

National Innovation Foundation-India, Satellite Complex, Satellite, Ahmedabad, Gujarat (380 015), India

\section{Article History}

Manuscript No. AR1604

Received in $23^{\text {rd }}$ May, 2016

Received in revised form $25^{\text {th }}$ September, 2016

Accepted in final form $5^{\text {th }}$ October, 2016

\section{Correspondence to}

*E-mail: ravikumar@nifindia.org

\section{Keywords}

Livestock, knowledge, social capital, women, technologies

\begin{abstract}
Sustaining farm income through effective, economical, and environment friendly technologies are imminent particularly in tropical countries. Enhanced expectation of people's aspiration, gap between haves and have-nots, and food security have been a challenge for public/private institutions to address. This gap can be bridged through indigenous knowledge system sustained by creative communities with resilience. However, successful intervention programs of engaging knowledge holders beyond documentation are limited. National Innovation Foundation, India has embarked upon larger research program in West Bengal (India). The primary objective was to generate meaningful evidence for promoting quality livestock health care through women knowledge holders. This is based on the Honey Bee Network philosophy that insists necessity to understand and imbibe values inherited by individual and/or community of knowledge system. The study highlights social capital gained by women knowledge holders which will form key determinant towards optimum utilization of these technologies. A model of incorporating indigenous veterinary medicine for benefit of farming community is illustrated. There is a need of supporting and reorienting veterinary service by public system to utilize and scale-up knowledge of society. Thus the study brings forth contribution of women knowledge holders within their social fabric. The paper articulates significance of social behaviour by conducting network meeting and an approach to engage hitherto less recognized technological alternatives for improvising quality livestock service.
\end{abstract}

\section{Introduction}

Developing countries have initiated programs for enhancing utilization of technology in different livestock production system. This has helped to generate technological demand and categorize farming community on the basis of rate of adoption of an innovation. There is a need to understand the production system before implementation of an animal health strategy (Etuk et al., 2005). A major challenge for research system is to characterize different farming systems for intensification (Robinson et al., 2015). Lack of community based strategies has been hindering agriculture conservation (Tschopp et al., 2010) and sustainable production. Further, in the entire process of technological intervention, values and norms of societies were not given due attention. Aspiration, an important sociopsychological phenomenon of self-development (Mali et al., 2015), has to be part of these activities. Listening farming communities has been a huge challenge to fulfil their needs and share values with empathy.
Rural societies in remote areas depend on plant based household remedies (Phondani et al., 2010). These indigenous practices can provide no or low cost remedies at farmer's doorstep (Ravikumar et al., 2015). Scientific experiments had proved utility of herbal medications to overcome livestock ailments (Kolte et al., 2008; Karangiya et al., 2016). Several research programs in the districts of Gujarat (India), viz. Amreli (Devgania et al., 2015), Gandhinagar (Bharwad et al., 2015; Kadivendi et al., 2015), Bhavnagar and Junagadh (Ravikumar et al., 2015a) indicated methodological approach for mainstreaming them. These reinforce importance of forming active utilizer system for agricultural development in less potential areas and for resource poor farmers (Roling, 1988). An eight steps model was also suggested for largescale demonstration of indigenous technologies for effective utilization in farmer's field (Ravikumar et al., 2016).

The reciprocity towards documented knowledge in ethical manner has been articulated globally by Honey Bee Network (Gupta, 2006). The ability of community to organize 
themselves for strengthening indigenous livestock system has been demonstrated which is important to sustain their wisdom. More than $50 \%$ of knowledge holders participated in network meeting in West Bengal were women (Ravikumar et al., 2015b). Society through creative communities can enhance the scope of such strategies (Surtia et al., 2016). This research paper articulates importance of learning from creative communities, their motivation, and inherent positive forces to forge partnership with them and the need for refinement, utilization of technologies by involving societies with specific reference to women.

\section{Materials and Methods}

The study was conducted in Purba Medinipur district of West Bengal (India) in 2013. Field investigation and personnel interview were conducted with identified knowledge holder(s) to document novel livestock medications. The research team had undertaken an active role in formation of Knowledge Network among knowledge holders of these regions. The primary aim was to understand nature of participation of knowledge holders specifically women healer and their interface with others. A regional workshop was conducted by seeking participation of knowledge holder at Bajkul, Purbamedinipur district. Efforts were made through this study to being out evidence of social participation by women healers through their wisdom and to share with community. The study examined role of social capital in terms of influence and network in enabling effective implementation of technologies derived from Indigenous system. This research work examines reinforcement of technological solutions from indigenous knowledge system through network meeting and to suggest an approach for implementation. The study tried to observe need for suitable change in institutional working arrangements towards scaling of livestock technologies.

\section{Results and Discussion}

\subsection{Significance of knowledge and social context}

Smt. Shatadal Ghorai, a widow of 55 years old tried to help her community through folkloric knowledge. She was illiterate and sustain her by performing household chores seeking support from the village. Under these contextual difficulties, she learnt medications from her father. Villagers relied on backyard poultry farming for food security. The nature of observation while treating affected birds helped her to explain specific signs of diseased birds. She narrated clinical symptoms of an ailment affecting poultry. The conditions narrated by her were illustrative of birds suffering from acute respiratory distress. This may be due to decreased immunity thereby spread of secondary bacterial organisms due to stress. The novel indigenous livestock medication was found effective. Villagers acknowledged her contribution in sharing and prescribing dosage in treatment of birds (NIF, 2015). Her medication enhanced immunity and protected birds against respiratory distress and secondary bacterial infection (Ghorai et al., 2016). Thus indigenous system provided necessary opportunity for Non Linear Innovation System [NLIS] approach (Kumar and Ravikumar, 2016). Development of technology through social knowledge can be mainstreamed by recognizing experimental spirit of communities outside formal system.

Social realities should be taken into account before executing a development intervention. Reaching to each birds through specific institutional unit of formal system is difficult. Farmer's accessibility to institutional services was also limited (Justus et al., 2013; Samal et al., 2003). The region bestowed with outstanding folkloric knowledge has to capitalize on these systems. In many regions of the World enhancing support to smallholder farmer is difficult and it affects the coping mechanisms of local livestock industry (Ndhlovu and Masika, 2013). The non-responsive of local treatment and nonavailability of traditional healers were other major constraints faced by the livestock owners (Gujar et al., 2015). It was in this perspective that protecting livestock health through community owned folkloric medications assume pragmatic. These knowledge systems had evolved to well-recognized resource constraints along with risks and uncertainties (Beckford and Barker, 2007). Indigenous system of veterinary medication has been operating with less or no monetary incentive in these social systems. With increasing concern on environmental health and poor industrial response to livestock sector, utility value of knowledge system has been changing. It is appropriate to have an update on these products or processes for developing and strengthening suitable models and frameworks (Simula et al., 2015).

\subsection{Nature of social participation}

A workshop was conducted in the study area wherein healers participated and shared their wisdom. The rationality of their behaviour helped the investigating team to know details of technologies and their implications. It was found that women knowledge holders stepped out of their homes to meet and discuss with other custodians of knowledge. This is important as in developing countries women have lesser degree of leadership role (Sraboni et al., 2014). Smt. Shatadal Ghorai, a poultry healer, could able to negate such norms through her knowledge and strived for equity with ease. Studies by Thakur et al. (2012) conducted in hilly regions reflected that majority of households had backyard poultry farming experience wherein they did not find difficulty in selling of poultry produce and women had greater control over it. They were confident in using indigenous medications in treating of livestock (Phondani et 
al., 2010) as they noticed the disease better due to their close association with them. Women were first observers owing to their close association in most activities related to livestock including home remedies (Tiwari and Pande, 2010). Thus, it has to be reiterated that women's participation can enhance productivity of rain-fed ecosystem and reduce vulnerability (Nirmala et al., 2012). These social interactions among creative communities can help to relate among themselves. The network meeting conducted by research team provided evidence wherein healers acknowledged learning from each other. It was also noticed that the nature of reciprocity among them was immense and responded with ethical standards of recognizing each other's contribution.

The desire to meet other healers to share their experience was likely through trust developed during course of the activities. These positive synergies helped National Innovation Foundation, India to form network of knowledge holders in these regions. Social network and social participation are important components of social capital (Willy and HolmMuller, 2013). The social capital gained out of these activities can be reaped for initiating suitable collective action. The study revealed that these social network and social influence were maintained based on knowledge without any external support. There are several steps to combine traditional healing system with contemporary medicine (Vansintejan, 1984). The research team tried to institutionalize the social capital obtained through healers' participation. However, for managing and sustaining these efforts public support is needed. A horizontal linkage among livestock healers through social participation may be one of the steps in effective implementation. This will help as livestock healers have desired knowledge and skill in sustaining them. There is a need to undertake effective research to understand the nature of motivation of healers who in spite of difficult social setting sustain creativity.

\subsection{Method of scaling-up}

The need of farming community can be addressed collectively by technology providers, viz. indigenous and formal systems. Indigenous system can provide opportunity for community to own their technology. These healers are present in most societies (Cheikhyoussef et al., 2011) who share their wisdom/ practice. Community participation can be mobilized through goodwill generated out of these low or no cost technologies (Ravikumar et al., 2016a). This will help in managing resources and extending livestock services in a sustainable manner. Studies by Nair et al. (1999) indicated that veterinarians treated livestock with indigenous medications depending upon their experience, place of working without completely depending on modern medicine. The nature of linkages among indigenous healers, owners and livestock service providers have to be strengthened. Public support is needed for enhancing the benefit and sensitizing users on indigenous wisdom. This is in agreement with Steinfeld (2003) as livestock sector requires proactive policies to support small-scale farmers. In most circumstances, these indigenous technologies survive through demand of livestock owners who can ill afford to take risks. Institutional innovations are needed in maximizing use of agro-ecological, human and financial resources for sustainable intensification (Schut et al., 2016). Sustainable production system as referred by Walters et al. (2016) should 'supply human needs, enhance environment and natural resource base, increase efficiency of resource use, improve economic viability of farming and quality of life for producers and society'. The effective interaction between formal institutional service providers and folkloric livestock healers were limited. This will enhance the scope of greater survival and discovery of the knowledge that can be put to use not only in niche specific areas but widely.

Thus these socially desirable technologies need to be incorporated in livestock development programs. Effective resources need to be allotted for encouraging wider diffusion of these novel technologies (Pani, 2016). Livestock extension service strategies are yet to be evolved in strengthening the knowledge system through successful demonstrations at diversified farm fields. Farmers in tropical countries try to supplement their income by keeping different species of livestock. There is a dearth of study to measure the impact of livestock ailment on livelihood and health including human values of rural poor. Poultry health plays a key role in poverty reduction, and development strategies need to incorporate human health as one of the components (Rist et al., 2015). Livestock health programs have to strategize these systems through holistic approach so as to complement public/private livestock service. This can be implemented by imagining the utility of folkloric wisdom by stakeholders. Organizing the local knowledge networks and their social influences plays a crucial role in scaling-up of indigenous system. There is an unique advantage of involving these practices as livestock production is predominantly a women-centric activity.

\section{Conclusion}

The technological gap in livestock production can be minimized through indigenous system. Women knowledge holders can learn under difficult social situation and demonstrated their ability to participate socially. This needs to be considered by formal system for providing quality livestock service. Creative spirit of informal knowledge holders and experimental nature of society can be harnessed for utilization and scaling-up of technologies for wider application. The study reiterates potential of these low cost technologies. 


\section{References}

Beckford, C., Barker, D., 2007. The role and value of local knowledge in Jamaican agriculture:adaptation and change in small-scale farming, The Geographical Journal 173(2), 118-128.

Bharwad, D., Vasan V., Kinhekar, A.S., Kumar, V., Ravikumar, R.K., Kumar, V., 2015. Therapeutic evaluation of indigenous veterinary medication for endoparasite infestation in Bovine under field conditions, Indian Journal of Applied Research 5(4), 755-756.

Cheikhyoussef, A., Shapi, M., Matengu, K., Ashekele, H.M., 2011. Ethnobotanical study of indigenous knowledge on medicinal plant use by traditional healers in Oshikoto region, Namibia, Journal of Ethnobiology and Ethnomedicine 7, 10. DOI: 10.1186/1746-4269-7-10.

Devgania, B.S., Khordia, D., Chodvadiya, M.B., Patel, R., Patel, D., Kinhekar, A.S., Singh, P.K., Kumar, V., Bhojne, G.R., Ravikumar, R.K., Kumar, V., 2015. Reverence of community towards grassroot livestock innovation: Responding to stakeholders need against sub-clinical mastitis in Amreli district, Gujarat, India. Advances in Animal and Veterinary Sciences 3(12), 689-693.

Etuk, E.B., Okoli, I.C., Ubedibie, A.B.I., 2005. Priority issues in tropical animal healthmanagement, Animal Production Research Advances 1(2), 83-92.

Ghorai, S., Ghorai, N., Dutta, L., Bera, A., Ghorui, S., Kinhekar, A.S., Ingle, V.C., Prashant S., Sudhakar, P.A., Prabhakar, A.T., Kumar, V., Ravikumar, R.K., Kumar, V., 2016. Protective effect of Indigenous Knowledge Research System [IKRS] against Ranikhet Disease Virus [RDV] from West Bengal, India, Journal of Immunology and Immunopathology, 18(1), 19-23. DOI: 10.5958/09739149.2016.00003.4.

Gujar, B., Rajput, D.S., Sharma, N.K., Goyal, T.C., Purohit, N.R., 2015. Constraints perceived by livestock owners related to organic animal husbandry practices, Ruminant Science 4(2), 195-198.

Gupta, A.K., 2006. From sink to source: the honey bee network documents indigenous knowledge and innovations in india, innovations: Technology, Governance, and Globalization 1(3), 49-66. Doi: doi:10.1162/itgg. 2006.1.3.49.

Justus, O., Owuor, G., Bebe, B.O., 2013. Management practices and challenges in smallholder indigenous chicken production in Western Kenya, Journal of Agriculture and Rural Development in the Tropics and Subtropics 114(1), 51-58.

Kadivendi, M., Maheshwari, R., Ravikumar, R.K., Chauhan, M.M., Kinhekar, A.S., Kumar, V., Kumar, V., 2015.
Integrated approach for engaging farming communityopportunities and challenges for low cost inputs, International Journal of Agriculture Innovations and Research 3(6), 1691-1695.

Karangiya, V.A., Savsani, H.H., Padodara, R.J., Ribadiya, N.K., Vekariya, S.J., 2016. Effect of garlic (Allium sativum) and ginger (Zingiber officinale) as feed additives on blood profile and broiler performance, The Indian Journal of Veterinary Sciences and Biotechnology 11(3), 1-4.

Kumar, V., Ravikumar, R.K., 2016. Realistic aspiration for livestock health care through indigenous veterinary system in India, Dairy of India 2016-17, 162-164.

Kolte, A.Y., Waghmare, S.P., Mode, S.G., Handa, A., 2008. Efficacy of indigenous herbal preparation on altered Milk pH, somatic cell count and electrolyte profile in subclinical mastitis in cows, Veterinary World 1(8), 239-240.

Mali, M.D., Tekale, V.S., Shaikh, J.I., 2015. Relationship between aspirations and personal, socio-economic and psychological characteristics of rural youth and constrains faced by rural youth towards self-development, Agriculture Update 10(2), 100-104.

Nair, S., Rao, S.V.N., Ramkumar, S., 1999. Perceptions of Veterinarians on ethno veterinary medicine, In: Mathias, E., Rangnekar, D.V., McCorkle, C.M. (Eds). Ethno veterinary medicine alternatives for livestock development, proceedings of an International conference held in Pune, India, 4-6 Nov 1997. BAIF Development Research Foundation, Pune, India, 243-249.

Ndhlovu, D.N., Masika, P.J., 2013. Ethno-veterinary control of bovine dermatophilosis and ticks in Zhombe, Njelele and Shamrock resettlement in Zimbabwe, Tropical Animal Health and Production 45, 525-532 DoI. 10.1007/ s11250-012-0253-7.

NIF., 2015. $8^{\text {th }}$ National Biennial Award Book, National Innovation Foundation-India, Ahmedabad, India, 52-53.

Nirmala, G., Ramana, D.B.V., Venkateswarlu, B., 2012. Women and scientific livestock management: improving capabilities through participatory action research in semi Arid areas of South India, APCBEE Procedia 4, 152-157.

Pani, N., 2016. Towards a socially consistent science and technology policy, Current Science 110(9), 1624-1629.

Phondani, P.C., Maikhuri, R.K., Kala, C.P., 2010. Ethnoveterinary uses of medicinal plants among traditional herbal healers in Alaknanda catchment of Uttarakhand, India, African Journal of Traditional, Complementary and Alternative Medicines 7(3), 195-206.

Schut, M., Asten, P.V., Okafor, C., Hicintuka, C., Mapatano, S., Nabahungu, N.L, Kagabo, D., Muchunguzi, P., Njukwe, 
E., Dontsop-Nguezet, P.M., Sartas, M., Vanlauwe, B., 2016. Sustainable intensification of agricultural systems in the central African highlands: The need for institutional innovation, Agricultural systems 145, 165-176.

Steinfeld, H., 2003. Economic constraints on production and consumption of animal source foods for nutrition in developing countries, The Journal of Nutrition 133, 4054S-4061S.

Ravikumar, R.K., Dutta, L., Kinhekar, A.S., Kumar, V., 2016. People's knowledge for addressing societal needs: Lessons learnt while engaging farming communities as a part of research system. Advances in Animal and Veterinary Sciences 4(1s), 1-8.

Ravikumar, R.K., Periyaveeturaman, C., Selvaraju, D., Kinhekar, A.S., Dutta, L., Kumar, V., 2016a. Community oriented ectoparasite intervention system: Concepts for on-farm application of indigenous veterinary medication. Advances in Animal and Veterinary Sciences 4(1s), 9-19.

Ravikumar, R.K, Kumar, V., Choudhary, H., Kinhekar, A.S., Kumar, V., 2015. Efficacy of indigenous polyherbalectoparasticide formulation against hard tick infestation in Cattle (Bos indicus), Ruminant Science $4(1), 43-47$.

Ravikumar, R.K., Kinhekar, A.S., Sahay, N.S., Kumar, V., Singh, P.K., Chodvadiya, M.B., Kumar, V., 2015 a. Methodological approach for sustaining indigenous veterinary knowledge of society: Case studies to control of endoparasite from the regions of Gandhinagar, Bhavnagar and Junagadh districts of Gujarat State, India, Indian Journal of Applied Research 5(10), 640-642.

Ravikumar, R.K., Dutta, L., Kumar, V., Kumar, V., 2015 b. Strengthening indigenous veterinary system-an approach for mobilizing community from West Bengal, Asian Academic Research Journal of Social Science and Humanities 1(34), 286-290.

Rist, C.S., Ngonghala, C.N., Garchitorena, A., Brook, C.E., Ramananjato, R., Miller, A.C., Randriannarivelojosia, M., Wright, P.C., Gillespie, T.R., Bonds, M.H., 2015. Modeling the burden of poultry disease on the rural poor in Madagascar, One Health 1, 60-65.

Robinson, L.W., Ericksen, P.J., Chesterman, S., Worden, J.S., 2015. Sustainable intensification in dry lands: What resilience and vulnerability can tell us, Agricultural Systems 135, 133-140
Roling, N., 1988. Extension science: Information systems in Agricultural Development, first edition, Cambridge University Press, Cambridge. Great Britain, 144-178.

Samal, P.K., Shah, A., Tiwari, S., Mehra, B., Agrawal, D.K., 2003. Indigenous animal health care practices in Indian Central Himalaya: Empirical evidences, Indian Journal of Traditional Knowledge 2(1), 40-50.

Simula, H., Hossain, M., Halme, M., 2015. Frugal and reverse innovation-Quo Vadis? Special section: Design for well being, Current Science 109(9), 1567-1572.

Sraboni, E., Malapit, H.J., Quisumbing, A.R., Ahmed, A.U., 2014. A woman's empowerment in agriculture: What role for food security in Bangladesh? World Development 61, $11-52$.

Surtia, G., Panchal, P., Patel, M., Ravikumar, R.K., Kumar, V., 2016. Improving livelihood initiatives through environmental friendly solutions derived from livestock by-product, International Journal of Science Environment and Technology 5(2), 658-665.

Thakur, D., Sharma, A.K., Ravikumar, R.K., Katoch, S., 2012. Status of backyard poultry farming in Himalayan regions of India, Indian Journal of Poultry Science 47(1), 102-105.

Tiwari, L., Pande, P.C., 2010. Ethno-veterinary medicines in Indian Perspective: Reference to Uttarakhand, Himalaya, Indian Journal of Traditional Knowledge 9(3), 611-617.

Tschopp, R., Aseffa, A., Schelling, E., Zinsstag, J., 2010. Farmer's perception of livestock, agriculture, and natural resources in the rural Ethiopian highlands, Mountain Research and Development 30(4), 381-390.

Vansintejan, G.A., 1984. A workshop for trainers of traditional birth attendants in Zaire, Journal of Nurse-Midwifery 29(1), 35-38. DoI:10.1016/0091-2182(84)90328-8.

Walters, J.P., Archer, D.W., Sassenrath, G.F., Hendrickson, J.R., Hanson, J.D., Halloran, J.M., Vadas, P., Alarcon, V.J., 2016. Exploring agricultural production systems and their fundamental components with system dynamics modelling, Ecological modelling 333, 51-65.

Willy, D.K., Holm-Muller, K., 2013. Social influence and collective action effects on farm level soil conservation effort in rural Kenya, Ecological economics 90, 94-103. 